\title{
Inhibition of PC3 human prostate cancer cell proliferation, invasion and migration by eicosapentaenoic acid and docosahexaenoic acid
}

\author{
KEIICHI OONO ${ }^{1}$, KATSUYA TAKAHASHI ${ }^{1}$, SAEKA SUKEHARA ${ }^{1}$, HIROHITO KUROSAWA $^{1}$, \\ TOMIO MATSUMURA ${ }^{2,3}$, SHUN'ICHIRO TANIGUCHI ${ }^{4}$ and SHOICHIRO OHTA $^{1}$
}

\author{
${ }^{1}$ Department of Clinical Pathology, Faculty of Pharmaceutical Sciences, Josai University, Sakado, Saitama 350-0295; \\ ${ }^{2}$ Institute for Biomedical Sciences, Interdisciplinary Cluster for Cutting Edge Research, Department of Advanced \\ Medicine for Health Promotion; ${ }^{3}$ Department of Molecular Oncology, Graduate School of Medicine; ${ }^{4}$ Department \\ of Comprehensive Cancer Therapy, School of Medicine, Shinshu University, Matsumoto, Nagano 390-8621, Japan
}

Received July 8, 2016; Accepted April 6, 2017

DOI: $10.3892 / \mathrm{mco} .2017 .1287$

\begin{abstract}
The n-3 fatty acids, eicosapentaenoic acid (EPA) and docosahexaenoic acid (DHA), found in fish oil, exert a number of beneficial effects, and they are used in the treatment of hyperlipidemia. In recent years, EPA and DHA have been found to affect cancer cell proliferation. In the present study, PC 3 cells, which are androgen-independent prostate cancer cells that resemble castration-resistant prostate cancer cells, were used to investigate a possible novel treatment for castration-resistant prostate cancer. The PC3 cells were cultured and incubated with various concentrations of EPA or DHA. Cancer proliferation was confirmed by trypan blue microscopy. Invasion and migration assays were used in the upper chamber in PC3 cells, and serum-free medium and various concentrations of EPA or DHA were placed in the lower chamber in serum-containing medium. EPA and DHA decreased PC3 cell proliferation, invasion and migration. The effect of EPA on PC 3 cells was dose-dependent and significant differences were observed at concentrations of 100 and $200 \mu \mathrm{g} / \mathrm{ml}$. The effect of DHA on PC3 cells was similar to that of EPA. In the migration assay, EPA exerted almost no effects at $25 \mu \mathrm{g} / \mathrm{ml}$, but migration was reduced at $50 \mu \mathrm{g} / \mathrm{ml}$. Similar to EPA, DHA exerted almost no effects at $25 \mu \mathrm{g} / \mathrm{ml}$, but further reduction was observed at the $50 \mu \mathrm{g} / \mathrm{ml}$ concentration. In the invasion assay, EPA at $25 \mu \mathrm{g} / \mathrm{ml}$ was not significantly different from the control, but suppressed invasion at $50 \mu \mathrm{g} / \mathrm{ml}$. DHA decreased invasion compared with the control at $25 \mu \mathrm{g} / \mathrm{ml}$, whereas invasion was significantly reduced at a DHA concentration of
\end{abstract}

Correspondence to: Professor Shoichiro Ohta, Department of Clinical Pathology, Faculty of Pharmaceutical Sciences, Josai University, 1-1 Keyakidai, Sakado, Saitama 350-0295, Japan

E-mail: sohtajp@josai.ac.jp

Key words: prostate cancer, PC3, eicosapentaenoic acid, docosahexaenoic acid, invasion assay
$50 \mu \mathrm{g} / \mathrm{ml}$. In conclusion, it was demonstrated that EPA and DHA were effective in decreasing the proliferation, invasion and migration of prostate PC 3 cancer cells. However, the detailed underlying mechanisms have not yet been fully elucidated.

\section{Introduction}

Eicosapentaenoic acid (EPA) and docosahexaenoic acid (DHA) are n-3 fatty acids that have several beneficial effects, including decreasing the plasma triglyceride concentration, lipoprotein metabolism (1,2), inhibiting platelet aggregation by collagen (3), and improving the reduced elasticity of the arterial walls through the endothelium-dependent relaxation response in rabbits (4). For these reasons, DHA and EPA are clinically used in Japan. In recent years, $n-3$ fatty acids have been shown to decrease the proliferation of cancer cells in colon, breast and liver cancer, as well as neuroblastoma. In addition, $n-3$ fatty acids may be used in cancer cachexia; the combination of chemotherapy and n-3 fatty acids was helpful in the curative as well as the palliative clinical setting (5), but a systematic review did not evaluate the balance of their cost-effectiveness against their utility (6). A number of studies have investigated cancer cell growth; however, only a limited number of studies have examined invasion and metastasis in prostate cancer, which exhibits an increasing prevalence. In the present study, the PC3 prostate cancer cell line was used, which is an androgen-independent human prostate cancer cell line that is similar to castration-resistant prostate cancer. A common metastatic organ in prostate cancer is bone, and the PC 3 cell line was derived from a bone-metastatic prostate cancer patient. Therefore, the aim of the present study was to determine whether EPA and DHA inhibit the proliferation, invasion and migration of PC3 cells, in order to explore a possible novel method for the treatment of castration-resistant prostate cancer.

\section{Materials and methods}

Proliferation. PC3 cells were grown in RPMI-1640 culture medium (Wako, Tokyo, Japan) supplemented with 5\% 
heat-inactivated fetal bovine serum (FBS), $100 \mathrm{U} / \mathrm{ml}$ penicillin and $100 \mu \mathrm{g} / \mathrm{ml}$ streptomycin (Wako). The cells were washed twice with phosphate-buffered saline (PBS; Wako) and serum-free RPMI-1640 containing 25, 50, 100, and $200 \mu \mathrm{g} / \mathrm{ml}$ EPA or DHA solution. Trypsin was added $24 \mathrm{~h}$ later, and an equal volume of trypan blue was added. The cell number was determined using light microscopy and a hemocytometer.

Migration and invasion assay. The migration and invasion assays were performed with Transwell membranes (pore size, $8 \mu \mathrm{m}$; Falcon, Tokyo, Japan) coated with Matrigel $^{\mathrm{TM}}$ matrix basement membrane (invasion assay), or without coating (migration assay). The cells $\left(2 \times 10^{5}\right)$ were suspended in the upper chamber of the Transwell inserts. The medium of the upper chamber was serum-free RPMI-1640 containing different concentrations of EPA or DHA. RPMI-1640 containing 10\% FBS was used as chemoattractant in the lower chamber. At 24 or $48 \mathrm{~h}$ after incubation, the cells were washed with PBS twice and cells on the upper chambers were removed with a cotton swab soaked in PBS. Migrating or invading cells were fixed with $100 \%$ methanol and stained with $0.1 \%$ crystal violet solution. Migrating or invading cells in four randomly selected fields on the underside of the inserts were counted under a light microscope.

Reagent and cell culture. EPA and DHA (Sigma-Aldrich, St. Louis, MO, USA) were dissolved in 99\% isopropanol. The desired concentration was reached by dilution in serum-free medium with $3 \%$ BSA. This solution was used for all studies. PC3 cells were cultured in RPMI-1640 medium in a 10-cm dish. When the cells were $70-80 \%$ confluent, they were passaged. After this step, the medium was changed at 24 and $48 \mathrm{~h}$.

\section{Results}

Effects of DHA and EPA on PC3 cell proliferation. EPA and DHA decreased PC3 cell proliferation. The effect of EPA on PC3 cells was dose-dependent and significant differences were observed at concentrations of 100 and $200 \mu \mathrm{g} / \mathrm{ml}$. The effect of DHA on PC3 cells was also significant at 100 and $200 \mu \mathrm{g} / \mathrm{ml}$ (Fig. 1). As seen in the photomicrographs of untreated and treated PC-3 cells, the number of surviving cells decreased gradually in response to the increasing concentrations of EPA and DHA (Fig. 2).

Effects of EPA and DHA on PC3 cell migration and invasion. EPA and DHA inhibited the invasion (Fig. 3) and migration (Fig. 4) of PC3 cells. In the invasion assay, EPA did not significantly inhibit invasion at a concentration of $25 \mu \mathrm{g} / \mathrm{ml}$ compared with the control, but significantly suppressed invasion at $50 \mu \mathrm{g} / \mathrm{ml}$. Invasion was significantly reduced at a DHA concentration of 25 and $50 \mu \mathrm{g} / \mathrm{ml}$. In the migration assay, DHA and EPA exerted almost identical effects at $25 \mu \mathrm{g} / \mathrm{ml}$, but further reduction of cell migration was observed at a concentration of $50 \mu \mathrm{g} / \mathrm{ml}$.

\section{Discussion}

The results of the present study demonstrated that EPA and DHA exert a potent effect on cancer cells. EPA and DHA
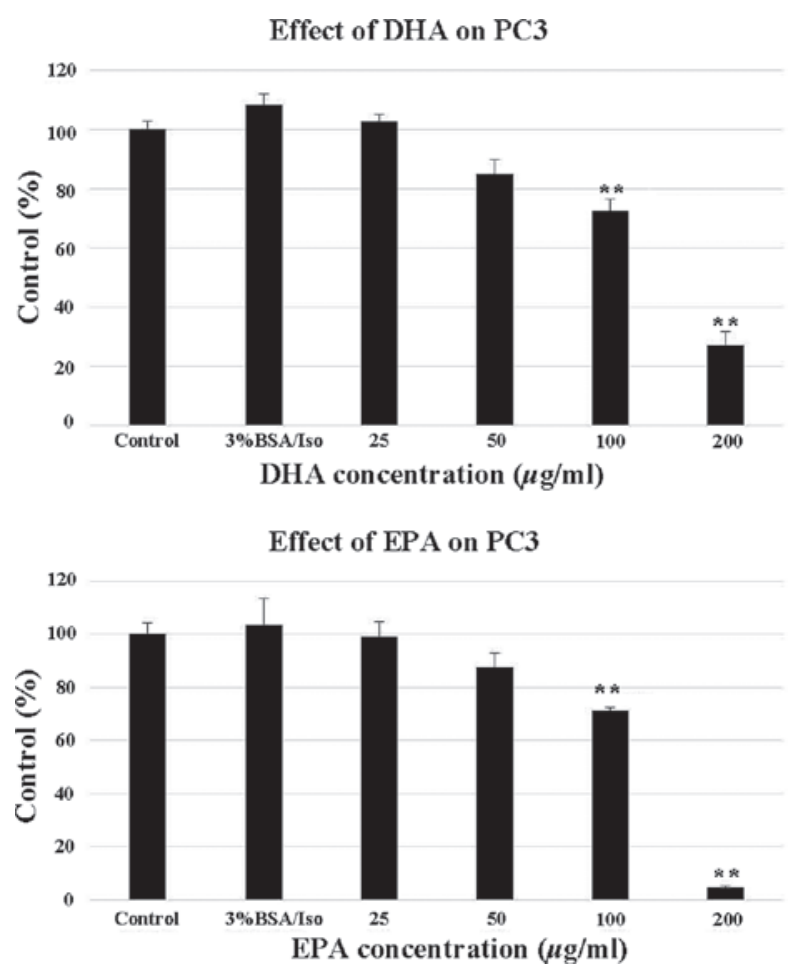

Figure 1. Effect of DHA (top panel) and EPA (bottom panel) on PC3 cell proliferation. At $24 \mathrm{~h}$ after seeding, various concentrations of DHA and EPA $(25,50,100$ and $200 \mu \mathrm{g} / \mathrm{ml})$ were added, with untreated cells as the control and $3 \% \mathrm{BSA} /$ Iso as the negative control. ${ }^{*} \mathrm{P}<0.05$ and ${ }^{* *} \mathrm{P}<0.01$ vs. control PC3 cells. EPA, eicosapentaenoic acid; DHA, docosahexaenoic acid; Iso, isopropanol; BSA, bovine serum albumin.

decreased the proliferation, invasion and migration in the PC3 prostate cancer cell line. Previous studies on this subject have used DU145, an androgen-independent prostate cancer cell line, obtained from brain metastasis of prostate cancer. It has been demonstrated the inhibitory effects of n-3 fatty acids on prostate cancer cells in culture suggest interference with growth factor signaling (7). It was also reported that $\mathrm{LNCaP}$ cell growth was inhibited by EPA and DHA (8). The effect of EPA and DHA on the proliferation and invasion of the breast cancer cell lines MDA-MB-231 and MDA-231 Luc and the effect of EPA and DHA on breast cancer metastasis to bone following intracardiac injection of MDA-MB-231 and MDA-231-Luc cells was also evaluated in other studies $(9,10)$. In brief, MDA-MB-231 cells were injected into mice that were fed experimental diets containing EPA or DHA. It was concluded that DHA inhibited the proliferation of cancer cells in bone metastasis compared with EPA (9). It was also demonstrated that there is an association between PC3 cell invasion and voltage-gated sodium channels; the data suggested that EPA inhibited the sodium current and downregulated sodium channel function (10).

As mentioned above, a study involving the DU145 prostate cancer cell line demonstrated that EPA decreased cell proliferation, the effect of DHA on proliferation did not differ significantly from the control (7). However, another study reported that EPA and DHA induced dose-dependent decreases in PC3 cell proliferation and the effects were similar between EPA and DHA (11).

In HT29 and HT29-dx colon cancer cells, omega-3 fatty acids inhibited cholesterol synthesis through ubitiquination 
Control (untreated)

EPA $25 \mu \mathrm{g} / \mathrm{ml}$

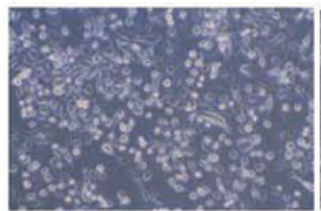

Control (untreated)

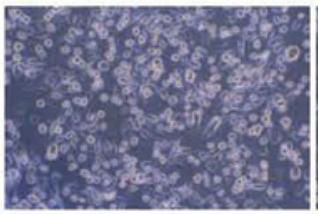

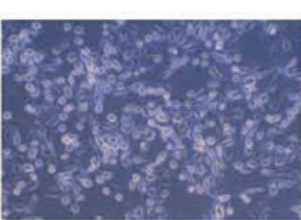

DHA $25 \mu \mathrm{g} / \mathrm{ml}$

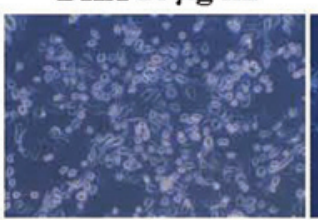

EPA $50 \mu \mathrm{g} / \mathrm{ml}$

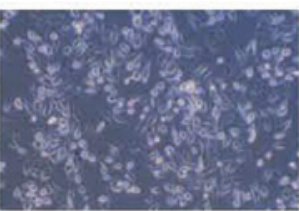

DHA $50 \mu \mathrm{g} / \mathrm{ml}$

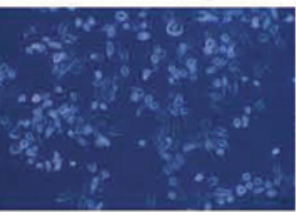

EPA $100 \mu \mathrm{g} / \mathrm{ml}$

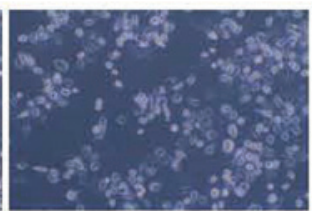

DHA $100 \mu \mathrm{g} / \mathrm{ml}$

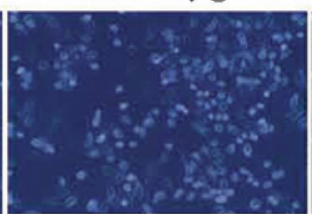

EPA $200 \mu \mathrm{g} / \mathrm{ml}$

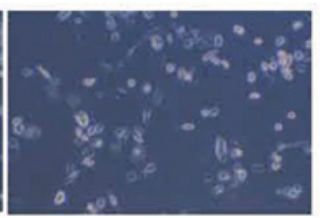

DHA $200 \mu \mathrm{g} / \mathrm{ml}$

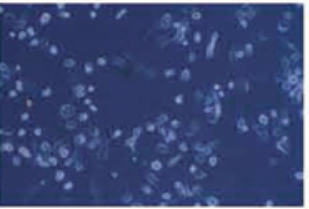

Figure 2. Photomicrographs of untreated and treated PC-3 cells. The number of surviving cells decreased gradually in response to the increasing concentrations of EPA and DHA. Control, untreated cells; EPA, eicosapentaenoic acid; DHA, docosahexaenoic acid.
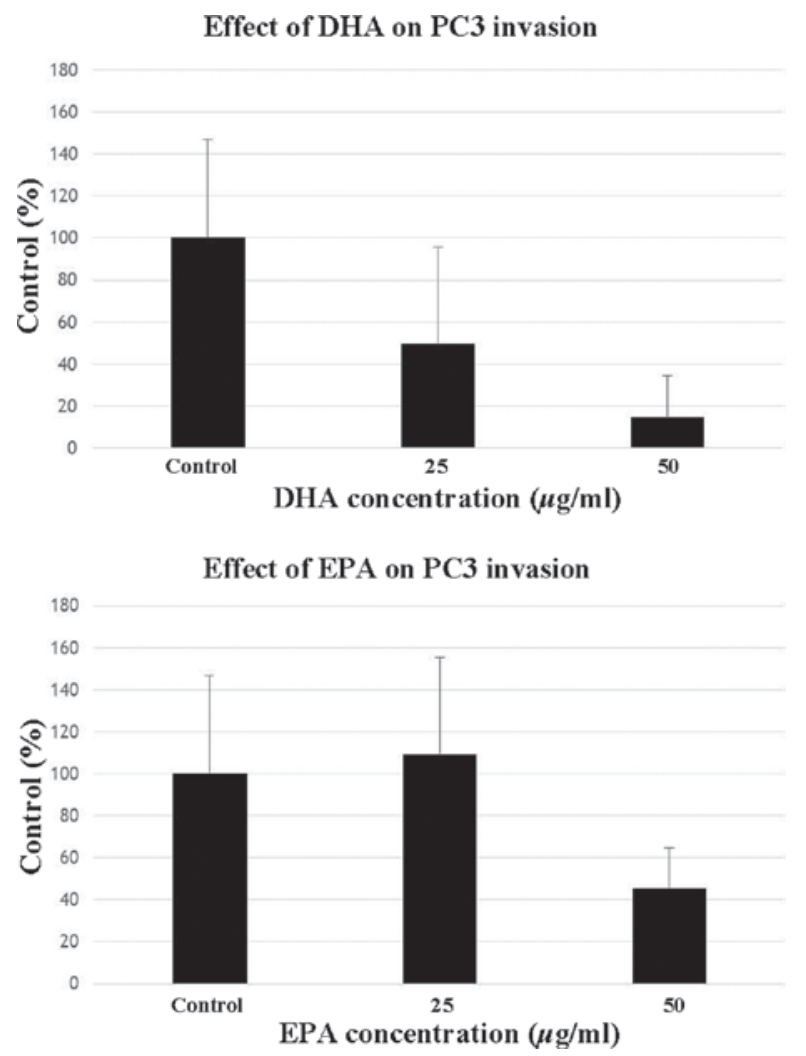

Figure 3. Effect of DHA (top panel) and EPA (bottom panel) on PC3 cell invasion. PC3 cells were seeded with Matrigel coating in the upper chamber and incubated with various concentrations of DHA or EPA $(25$ and $50 \mu \mathrm{g} / \mathrm{ml})$ with $10 \%$ fetal bovine serum-supplemented medium in the lower chamber After $40 \mathrm{~h}$, the number of invading cells was counted. Data are presented as mean \pm standard error (data from 3 different experiments). ${ }^{*} \mathrm{P}<0.05$ and ${ }^{* *} \mathrm{P}<0.01$ vs. control PC3 cells. EPA, eicosapentaenoic acid; DHA, docosahexaenoic acid.

of HMG-CoA reductase. The inhibition of HT29 cell proliferation and cholesterol synthesis was correlated with cell viability (12).

The addition of EPA, DHA and $\alpha$-linoleic acid has been shown to decrease proliferation in neuroblastoma IMR-32 cells in a study investigating the effect of eicosanoids, such as lipoxin A4, prostaglandin and leukotriene, on IMR-32 cells (13).

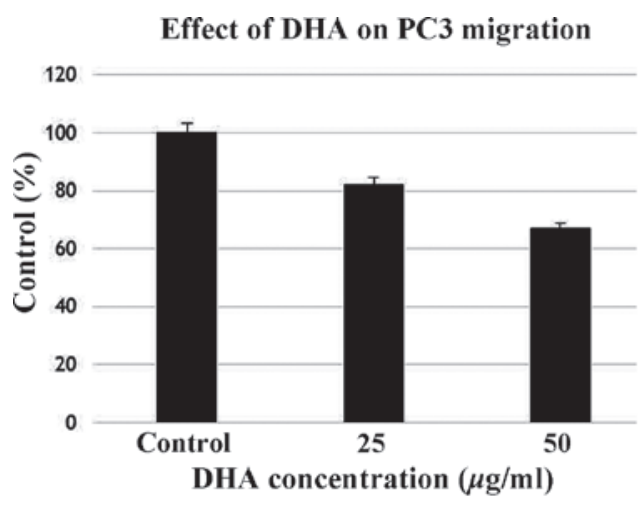

Effect of EPA on PC3 migration

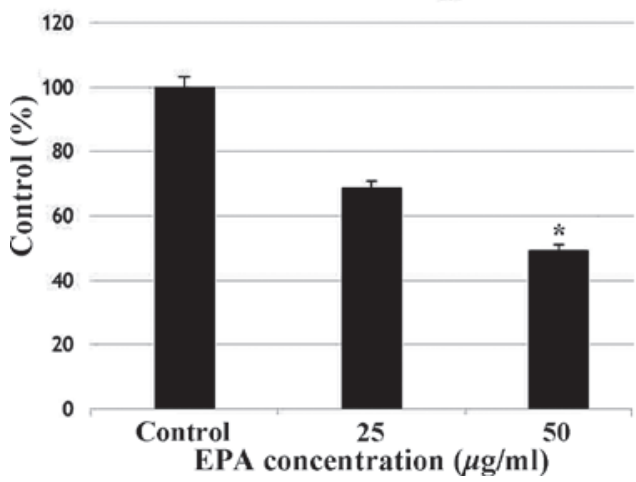

Figure 4. Effect of DHA (top panel) and EPA (bottom panel) on PC3 cell migration. PC3 cells were seeded in the upper chamber and incubated with various concentrations of DHA or EPA ( 25 and $50 \mu \mathrm{g} / \mathrm{ml})$ with $10 \%$ fetal bovine serum-supplemented medium in the lower chamber. After $24 \mathrm{~h}$, the number of migrating cells was counted. Data are presented as mean \pm standard error (data from 3 different experiments). ${ }^{*} \mathrm{P}<0.05$ and ${ }^{* *} \mathrm{P}<0.01$ vs. control PC3 cells. EPA, eicosapentaenoic acid; DHA, docosahexaenoic acid.

A study involving HepG2 cells and normal human liver L-02 cells demonstrated that HepG2 cell proliferation decreased dose-dependently with EPA treatment. The effect was not different between incubation times of 24 and $48 \mathrm{~h}$, but L-02 cell proliferation was not affected by EPA. In addition, the study reported that EPA induced the degradation of pro-caspase-9 and pro-caspase-3 in HepG2 cells, through induction of MPTP and release of cytochrome C 
from the mitochondria to the cytoplasm in a time-dependent manner (14).

Those studies demonstrated that EPA and DHA decreased cancer cell proliferation. EPA and DHA exerted a number of effects, including changes in intracellular ion concentration, ubiquitination, and the inhibition of multidrug resistance proteins. Our results demonstrated that EPA decreased cancer proliferation more efficiently compared with DHA, suggesting a possible treatment for metastatic castration-resistant prostate cancer. In addition, PC 3 cells expressed phosphoinositide 3 kinase (PI3K)/AKT-related PIP5K1 $\alpha$ (15), and HBx transfection in HepG2 cells led to the expression of nuclear factor $(\mathrm{NF})-\kappa \beta$ (16). NF- $\kappa \beta$ is downstream of $\mathrm{PI} 3 \mathrm{~K} / \mathrm{AKT}$ and is a transcription factor that acts on a variety of genes. However, those studies did not demonstrate the effects of EPA and DHA, although EPA and DHA were shown to inhibit NF-к $\beta(17,18)$. Therefore, similar effects may also be expected in PC3 cells, although the underlying mechanisms in PC3 cells require further elucidation.

In conclusion, EPA and DHA inhibited invasion and migration as well as proliferation of PC-3 cells. Furthermore, it has been demonstrated that EPA and DHA exerted independent effects on decreasing the proliferation and invasion of prostate PC3 cancer cells. However, the detailed underlying mechanisms have not yet been fully elucidated.

\section{References}

1. Harris WS: Fish oils and plasma lipid and lipoprotein metabolism in humans: A critical review. J Lipid Res 30: 785-807, 1989.

2. Ikeda I, Cha JY, Yanagita T, Nakatani N, Oogami K, Imaizumi K and Yazawa K: Effects of dietary alpha-linolenic, eicosapentaenoic and docosahexaenoic acids on hepatic lipogenesis and beta-oxidation in rats. Biosci Biotechnol Biochem 62: 675-680, 1998.

3. Sato M, Karsuki Y, Fukuhara K, Kawano K, Mizota M, Hamada Y and Kunihiro Y: Effects of highly purified all-cis-5,8,11,14,17-icosapentaenoate (EPA-E) on rabbit platelets. Biol Pharm Bull 16: 362-367, 1993.

4. Sato M, Katsuki Y, Kanehiro H, Kawano H and Mizota M: Effects of ethyl all-cis-5,8,11,14,17-icosapentaenoate (EPA-E) on elasticity and endothelium-dependent relaxation of the aorta in high cholesterol diet-fed rabbits. Nihon Yakurigaku Zasshi 104: 31-38, 1994 (In Japanese).

5. Laviano A, Rianda S, Molfino A and Fanelli F: Omega-3 fatty acids in cancer. Curr Opin Clin Nutr Metab Care 16: 156-161, 2013.

6. Colomer R, Moreno-Nogueira JM, García-Luna PP, García-Peris P, García-de-Lorenzo A, Zarazaga A, Quecedo L, del Llano J, Usán L and Casimiro C: n-3 fatty acids, cancer and cachexia: A systematic review of the literature. Br J Nutr 97: 823-831, 2007.

7. Liu Z, Hopkins MM, Zhang Z, Quisenberry CB, Fix LC, Galvan BM and Meier KE: Omega-3 fatty acids and other FFA4 agonists inhibit growth factor signaling in human prostate cancer cells. J Pharmacol Exp Ther 352: 380-394, 2015.
8. Eser PO, Vanden Heuvel JP, Araujo J and Thompson JT: Marineand plant-derived $\omega-3$ fatty acids differentially regulate prostate cancer cell proliferation. Mol Clin Oncol 1: 444-452. 2013

9. Rahman MM, Veigas JM, Williams PJ and Fernandes G: DHA is a more potent inhibitor of breast cancer metastasis to bone and related osteolysis than EPA. Breast Cancer Res Treat 141: 341-352, 2013.

10. Nakajima T, Kubota N, Tsutsumi T, Oguri A, Imuta H, Jo T, Oonuma H,Soma M, Meguro K, Takano H, et al: Eicosapentaenoic acids inhibits voltage-gated sodium channels and invasiveness in prostate cancer cells. Br J Pharmacol 156: 420-431, 2009.

11. Li CC, Hou YC, Yeh CL and Yeh SL: Effect of eicosapentaenoic acid and docosahexaenoic acid on prostate cancer cell migration and invasion induced by tumor-associated macrophages. Plos One 9: e99630, 2014.

12. Gelsomino G, Corsetto PA, Campia I, Montorfano G, Kopecka J, Castella B, Gazzzano E, Ghigo D, Rizzo AM and Riganti C: Omega 3 fatty acids chemosensitize multidrug resistant colon cancer cells by down-regulating cholesterol synthesis and altering detergent resistant membranes composition. Mol Cancer 12: 137, 2013.

13. Polavarapu P, Mani AM, Gundala NK, Hari AD, Bathina S and Das UN: Effect of polyunsaturated fatty acids and their metabolites on bleomycin-induced cytotoxic action on human neuroblastoma cells in vitro. Plos One 10: e114766, 2014.

14. Zhang Y, Han L, Qi W, Cheng D, Ma X, Hou L, Cao X and Wang C: Eicosapentaenoic acid (EPA) induced apoptosis in HepG2 cells through ROS-Ca(2+)-JNK mithochondrial pathway. Biochem Biophys Res Commun 456: 926-932, 2015.

15. Semenas J, Hedblom A, Miftakhova RR, Sarwar M, Larsson R, Shcherbina L, Johansson ME, Harkonen P, Sterner O and Persson JL: The role of PI3K/AKT-related PIP5K1 $\alpha$ and the discovery of its selective inhibitor for treatment of advanced prostate cancer. Proc Natl Acad Sci USA 111: E3689-E3698, 2014.

16. Chan CF, Yau TO, Jin DY, Wong CM, Fan ST and Ng IO: Evaluation of nuclear factor-kappaB, urokinase-type plasminogen activator, and $\mathrm{HBx}$ and their clinicopathological significnce in hepatocellular carcinoma. Clin Cancer Res 10: 4140-4149, 2004.

17. Draper E, Reynolds CM, Canavan M, Mills KH, Loscher CE and Roche HM: Omega-3 fatty acids attenuate dendritic cell function via NF- $\kappa \beta$ independent of PPAR $\gamma$. J Nutr Biochem 22: 784-790, 2011.

18. Wang Y, Lin QW, Zheng PP, Zhang JS and Huang F: DHA inhibits protein degradation more efficiently than EPA by regulating the PPAR $\gamma / \mathrm{NF}-\kappa \beta$ pathway in $\mathrm{C} 2 \mathrm{C} 12$ myotubes. Biomed Res Int 2013: 318981, 2013. 